Research Paper

\title{
Integrin a $2 \beta 1$ decelerates proliferation, but promotes survival and invasion of prostate cancer cells
}

\author{
Marjaana Ojalill ${ }^{1}$, Marjaana Parikainen ${ }^{1}$, Pekka Rappu ${ }^{1}$, Elina Aalto ${ }^{1}$, Johanna \\ Jokinen $^{1}$, Noora Virtanen ${ }^{1}$, Elina Siljamäki ${ }^{1}$ and Jyrki Heino ${ }^{1}$ \\ ${ }^{1}$ Department of Biochemistry, University of Turku, Turku, Finland \\ Correspondence to: Jyrki Heino, email: jyrki.heino@utu.fi \\ Keywords: prostate cancer; cancer stem cells; integrin; cell adhesion; p38 \\ Received: April 30, $2018 \quad$ Accepted: July 21, $2018 \quad$ Published: August 21, 2018 \\ Copyright: Ojalill et al. This is an open-access article distributed under the terms of the Creative Commons Attribution License 3.0 \\ (CC BY 3.0), which permits unrestricted use, distribution, and reproduction in any medium, provided the original author and source \\ are credited.
}

\section{ABSTRACT}

High expression level of integrin a2 21 is a hallmark of prostate cancer stem cell like cells. The role of this collagen receptor is controversial since it is down regulated in poorly differentiated carcinomas, but concomitantly proposed to promote metastasis. Here, we show that docetaxel resistant DU145 prostate cancer cells express high levels of $\alpha 2 \beta 1$ and that $\alpha_{2} \beta 1^{\text {High }}$ subpopulation of DU145 cells proliferates slower than the cells representing $\alpha 2 \beta 1^{\text {Low }}$ subpopulation. To further study this initial observation we used Crispr/Cas9 technology to create an a2ß1 negative DU145 cell line. Furthermore, we performed rescue experiment by transfecting a 2 knockout cells with vector carrying a 2 cDNA or with an empty vector for appropriate control. When these two cell lines were compared, a2 $\beta 1$ positive cells proliferated slower, were more resistant to docetaxel and also migrated more effectively on collagen and invaded faster through matrigel or collagen. Integrin a2 $\beta 1$ was demonstrated to be a positive regulator of p38 MAPK phosphorylation and a selective p38 inhibitor (SB203580) promoted proliferation and inhibited invasion. Effects of a2 $\beta 1$ integrin on the global gene expression pattern of DU145 cells in spheroid cultures were studied by RNA sequencing. Integrin a $2 \beta 1$ was shown to regulate several cancer progression related genes, most notably matrix metalloproteinase-1 (MMP-1), a recognized invasion promoting protein. To conclude, the fact that $a 2 \beta 1$ decelerates cell proliferation may explain the dominance of a $2 \beta 1$ negative/low cells in primary sites of poorly differentiated carcinomas, while the critical role of a2 $\beta 1$ integrin in invasion stresses the importance of this adhesion receptor in cancer dissemination.

\section{INTRODUCTION}

Integrin $\alpha 2 \beta 1$ is an abundant collagen receptor expressed mainly on epithelial cells and platelets. Additionally, many mesenchymal cells are $\alpha 2 \beta 1$ positive. This collagen receptor shows higher avidity to fibril forming collagens than to e.g. basement membrane collagen IV [1]. Integrin $\alpha 2 \beta 1$ also has a large number of other extracellular matrix (ECM) related ligands, such as tenascin C [2], laminins [3], proteoglycans endorepellin/ perlecan [4] and decorin [5]. Experiments with $\alpha 2$ deficient mice have shown that this receptor is required in e.g. immune response, angiogenesis and platelet function [6-10].

In prostate cancer the role of $\alpha 2 \beta 1$ has remained unclear, despite the fact that the prostate stem cells, and accordingly the prostate cancer stem cell like cells, have been described to be $\alpha 2 \beta 1^{\text {High }}, \mathrm{CD} 44^{\mathrm{High}}$, Trop $2^{\mathrm{High}}$, $\mathrm{CD}_{133^{+}}$and integrin $\alpha 6^{+}$cells [11-13]. Paradoxically, the expression of $\alpha 2 \beta 1$ is down regulated during prostate cancer progression $[14,15]$, but many studies propose an important role for $\alpha 2 \beta 1$ in bone metastasis [16-18]. The interplay between androgen receptor and $\alpha 2 \beta 1$ integrin expression [19] may partially explain the controversy. 
Integrin $\alpha 2 \beta 1$ mediated signaling can activate $\mathrm{p} 38$ $[20,21]$ and ERK mitogen activated protein kinases (MAPKs) [22], and the signaling has been reported to either promote $[22,23]$ or inhibit cell proliferation [24, $25]$. The cellular functions of $\alpha 2 \beta 1$ may be dependent on the organization of the surrounding ECM, since there are observations that collagen fibrils and monomers activate distinct signaling events [24, 25]. Moreover, there is significant cross-talk between integrins and growth factor receptors [26]. In the case of $\alpha 2 \beta 1$ at least platelet derived growth factor receptor [27], epidermal growth factor receptor [28] and hepatocyte growth factor receptor (c-met) [29] modify integrin expression or functions. Inhibition of cell division by fibrillar collagen has also been linked to the activation of $\mathrm{p} 27^{\mathrm{KIP} 1}$, an inhibitor of cyclin-dependent kinase 2 [24, 25].

To study the paradoxical role of $\alpha 2 \beta 1$ integrin in prostate cancer we used Crispr/Cas9 technology to create an $\alpha 2$ integrin negative DU145 cell line and cDNA transfections to rescue $\alpha 2$ integrin, and an appropriate control ( $\alpha 2$ integrin negative) cell line. We tested the cells in a spheroid model to mimic 3-dimensional tissue conditions. Our observations indicate that $\alpha 2$ integrin is a negative regulator of prostate cancer cell proliferation, but that it concomitantly promotes survival, drug resistance and invasion. Furthermore, the data from the RNA sequencing indicate that $\alpha 2$ integrin regulates the expression of several cancer progression and invasion related genes. Thus, $\alpha 2 \beta 1$ integrin may play a critical role in the protection of the stem cell like cells and in the invasion and metastasis.

\section{RESULTS}

\section{Docetaxel resistant DU145 cells express high levels of $\alpha 2 \beta 1$ integrin and the $\alpha 2 \beta 1^{\text {High }}$ subpopulation of DU145 cells proliferates slower than the $\alpha 2 \beta 1^{\text {Low }}$ subpopulation}

DU145 is an $\alpha 2 \beta 1$ integrin positive prostate cancer cell line [19] originally derived from a central nervous system metastasis. In general, prostatic epithelial cells and prostate cancer cells are known to use $\alpha 2 \beta 1$ integrin in adhesion to various collagen subtypes and bone matrix $[16,17,30]$. We exposed DU145 cells to $50 \mathrm{nM}$ docetaxel and measured their $\alpha 2 \beta 1$ and CD44 expression levels by flow cytometry before and after the treatment. The surviving cells expressed significantly higher $\alpha 2 \beta 1$ levels than untreated cells (Figure 1A, 1B). The result was the same when the cells were plated either on collagen I or fibronectin (Figure 1A, 1B). Docetaxel is known to block mitosis by inhibiting mitotic spindle assembly, accordingly here DU145 cells treated with $50 \mathrm{nM}$ docetaxel were significantly converted from G1 to G2/M phase (Supplementary Figure 1A, 1B). The high $\alpha 2 \beta 1$ expression could be linked to survival also without ligand binding by $\alpha 2 \beta 1$ integrin. Similarly, the surviving cells expressed more CD44 (Figure 1A, 1B), suggesting that the cells with stem cell markers might be more drug resistant. The most probable reason for the decreased sensitivity was speculated to be the potentially lower proliferation rate of $\alpha 2 \beta 1^{\text {High }} / \mathrm{CD} 44^{\text {High }}$ cells.

To further test this hypothesis we selected DU145$\alpha 2 \beta 1^{\text {High }}$ and DU145- $\alpha 2 \beta 1^{\text {Low }}$ subpopulations by using specific antibodies and sorting flow cytometry (Figure 1C) and examined their proliferation on collagen I, fibronectin and poly-1-lysin (Figure 1E). The results indicated that the number of $\alpha 2 \beta 1^{\text {High }}$ cells increased slower that $\alpha 2 \beta 1^{\text {Low }}$ cells and that the difference was not dependent on the binding of $\alpha 2 \beta 1$ to its ligand, collagen I. Interestingly, the cells selected based on their high $\alpha 2 \beta 1$ integrin expression levels also expressed high levels of CD44, but there was no difference in Trop2 expression levels (Figure 1D). Thus, we concluded that $\alpha 2 \beta 1^{\text {High }} / \mathrm{CD} 44^{\text {High }}$ DU145 cells proliferate slower than DU145 cells in general. However, these results only indicated an association between $\alpha 2 \beta 1$ integrin, survival and proliferation, and further experiments were needed to study the functions of $\alpha 2 \beta 1$ integrin in cell regulation.

\section{In a genetic model $\alpha 2$ integrin positive DU145 cells proliferate slower and are more resistant to docetaxel than $\alpha 2$ integrin negative cells}

We successfully used Crispr/Cas9 technology to create $\alpha 2$ integrin negative DU145 cells (DU145KO). The realization of knockout was confirmed by sequencing the PCR product received in the amplification of genomic DNA in the area of interest (Supplementary Figure 2). We did not, however, consider DU145WT (wild type) versus DU145KO to be an optimal pair for comparisons for two reasons: i) DU145WT (wild type) cells were indicated to be a mixture of $\alpha 2 \beta 1^{\text {High }}$ and $\alpha 2 \beta 1^{\text {Low }}$ cells with distinct properties, and ii) complex transfection and selection procedure may have had unpredicted influences on the DU145KO cell line. Therefore we used cDNA transfections to create two more cells lines: DU145KO $+\alpha 2$ that has rescued expression of $\alpha 2$ integrin and an $\alpha 2$ negative vector control DU145KO+vector line (Figure $2 \mathrm{~A}, 2 \mathrm{~B})$. The $\alpha 2 \beta 1$ expression levels were confirmed using specific antibodies in flow cytometry (Figure 2A) and western blotting (Figure 2B). Overexpression of $\alpha 2$ integrin had no effect on the CD44 expression level on cell surface (Figure 2C). Thus the two stem cell markers are not directly regulated by each other.

The proliferation of the two cell lines was tested in spheroids instead of monolayer cultures since $\alpha 2 \beta 1$ integrin specific signaling may be more apparent in $3 \mathrm{D}$ environment [1]. We tested the proliferation of $\alpha 2$ positive DU145KO $+\alpha 2$ and $\alpha 2$ negative DU145KO+vector cells by measuring the increase in the DNA content of the spheroids. The spheroids formed by $\alpha 2$ negative cells 
were slightly more compact and therefore had smaller diameter (Figure 2D), but the amount of DNA in these spheroids increased significantly faster indicating higher cell proliferation rate (Figure 2E). When the resistance to docetaxel was measured using a colony survival assay, $\alpha 2 \beta 1$ positive cells were significantly more resistant to this drug than their $\alpha 2$ negative counterparts on collagen, but not on fibronectin (Figure 2F).

\section{$\alpha 2$ positive DU145 cells are more invasive than $\alpha 2$ negative cells}

We speculated that the loose growth mode of $\alpha 2$ positive cells in spheroids may be due to increased cell mobility and therefore we established both cell migration and invasion assays. DU $145 \mathrm{KO}+\alpha 2$ cells showed significantly higher rate of invasion through matrigel
A
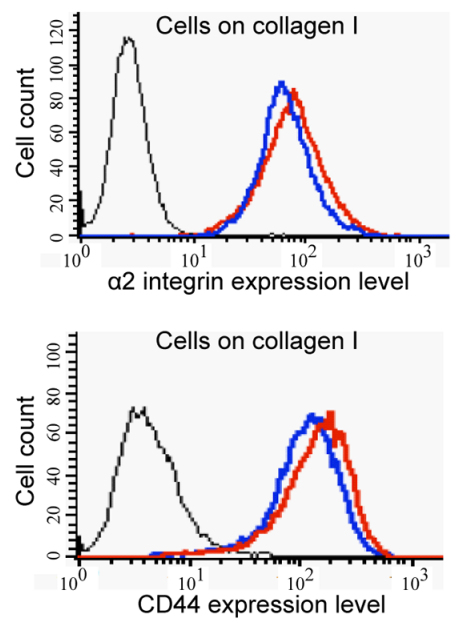

C

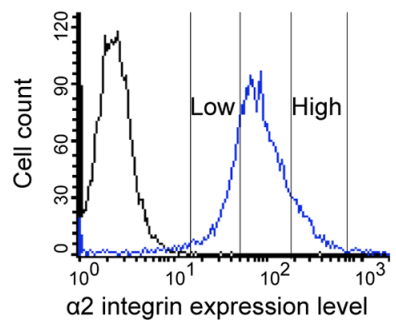

E

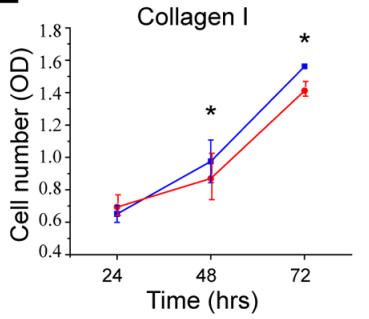

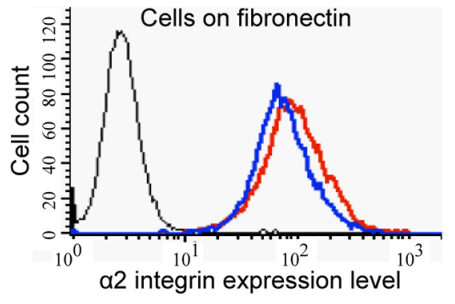

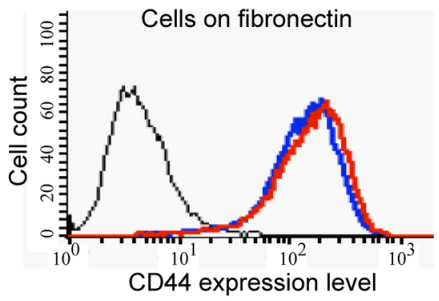

- $0 \mathrm{nM}$ Docetaxel $\quad 50 \mathrm{nM}$ Docetaxel

\section{D}
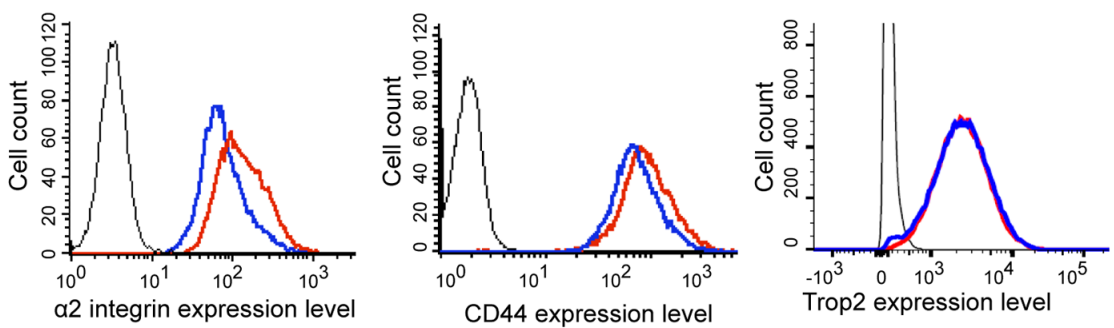

- Control

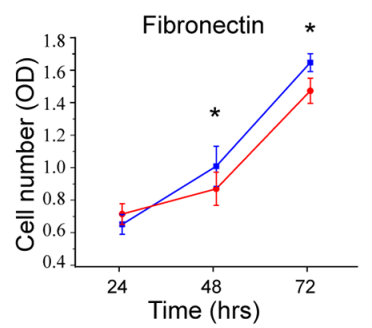

B
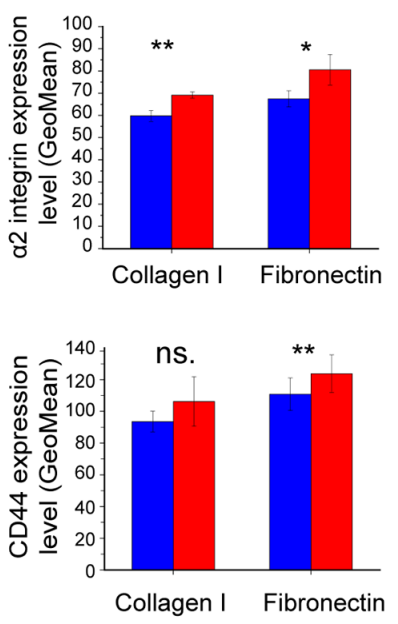

Figure 1: DU145 cells that survive docetaxel treatment show increased expression of stem cell markers: $\alpha 2$ integrin and CD44. (A) The representative FACS plots show increased surface expression levels of $\alpha 2$ integrin and CD44 on cells that have been on collagen I or on fibronectin $\left(5 \mu \mathrm{g} / \mathrm{cm}^{2}\right)$ coated plates and treated with $50 \mathrm{nM}$ Docetaxel for 24 hours. (B) The quantification of $\alpha 2$ integrin and CD44 cell surface expression based on GeoMean values. Data as mean $\pm \mathrm{SEM}(\mathrm{n}=3) .{ }^{*}=\mathrm{P}<0.05 ;{ }^{* *}=\mathrm{P}<0.01$; ns. $=$ not significant. (C) The FACS plot illustrates the sorting of DU145WT cells into DU145WT ( $\left.\alpha 2^{\text {High }}\right)$ and DU145WT $\left(\alpha 2^{\text {Low }}\right)$ subpopulations based $\alpha 2$ integrin expression level on cells. (D) Representative FACS plots for $\alpha 2$ integrin, CD44 and Trop2 expression on DU145WT ( $\left.\alpha 2^{\text {High }}\right)$ and DU145WT $\left(\alpha 2^{\text {Low }}\right)$ subpopulations analyzed in the 5th passages after sorting. (E) Quantification of the proliferation of DU145WT $\left(\alpha 2^{\text {High }}\right)$ subpopulation compared to DU145WT $\left(\alpha 2^{\text {Low }}\right)$ subpopulation on collagen I, fibronectin and poly-1-lysine measured with the WST- 8 assay. Data are mean absorbance values (OD) at $490 \mathrm{~nm}(\mathrm{n}=3){ }^{*}{ }^{*}=\mathrm{P}<0.05$. 
in transwell assay when compared to DU145WT or DU145KO+vector cells (Figure 3A). We also tested the cells in another type of assay, in which 3 day spheroids were plated on collagen I (Figure 3B, migration assay) or embedded between collagen layers (Figure 3C, invasion assay) and the diameter of the area covered by cells was measured every 24 hours during 4 days. DU145KO $+\alpha 2$ cells migrated (Figure 3B) and invaded (Figure 3C) significantly faster than their $\alpha 2$ negative counterparts.

The difference in the migration rate between $\alpha 2 \beta 1^{\text {High }}$ and $\alpha 2 \beta 1^{\text {Low }}$ cells was also evident when another prostate cancer cell line, PC3 was tested. These cells differ from DU145 in many characteristics, e.g. PC3 $\alpha 2 \beta 1^{\text {High }}$ cells have lower CD44 expression levels than PC3 $\alpha 2 \beta 1^{\text {Low }}$ cells. At the same time the expression level of Trop2 is much higher in PC3 $\alpha 2 \beta 1^{\text {High }}$ cells. In agreement with our DU145 cell results, PC 3 cells that survive docetaxel treatment have high $\alpha 2$ integrin expression level. The results with PC3 cells are shown in Supplementary Figure 3.

\section{Activation of p38 MAPK mediates the effects of $\alpha 2 \beta 1$ on cell proliferation and invasion}

In many cell types, integrin $\alpha 2 \beta 1$ signaling is known to induce the phosphorylation of focal adhesion kinase
(FAK) [31] and activate growth promoting ERK MAPkinase [21]. Integrin $\alpha 2 \beta 1$ has also frequently been linked to the phosphorylation of p38 MAPK [20, 21]. Here, we plated $\alpha 2$ negative DU145KO+vector cells and $\alpha 2$ positive DU145KO $+\alpha 2$ cells on collagen and measured the activation of FAK, ERK and p38 by western blotting. The phosphorylation of all three proteins was clearly more prominent in $\alpha 2$ positive cells (Figure 4A).

Next we tested the effect of selective p38 inhibitor SB203580 on cell proliferation, invasion and migration. The inhibition of p38 by SB203580 was confirmed by measuring the phosphorylation of downstream signaling protein CREB (cAMP response element-binding protein). In DU145WT and DU145KO $+\alpha 2$ cells the treatment with SB203580 $(10 \mu \mathrm{g} / \mathrm{ml})$ resulted in $40-50 \%$ reduction of CREB activation (Supplementary Figure 4A, 4B). SB203580 increased significantly the proliferation (the amount of DNA) in spheroid cultures of DU145KO $+\alpha 2$ cells at $48 \mathrm{~h}$ time point (Figure 4B). It also slightly enhanced the proliferation of $\alpha 2$ negative cells, but the increase was not statistically significant (Figure 4B).

In the migration and invasion assays SB203580 was a potent inhibitor of DU145KO+ 2 cells (Figure $4 \mathrm{C}$, 4D). In the presence of the p38 inhibitor the migration and invasion by these cells were reduced to the same
A

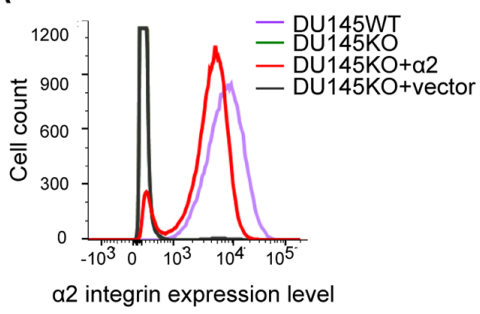

B

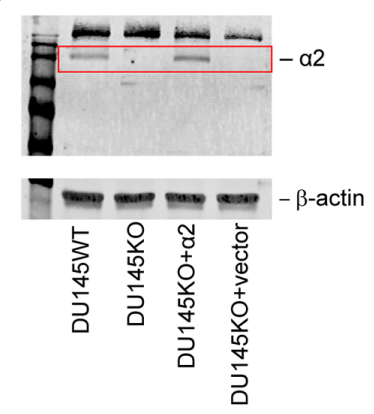

C

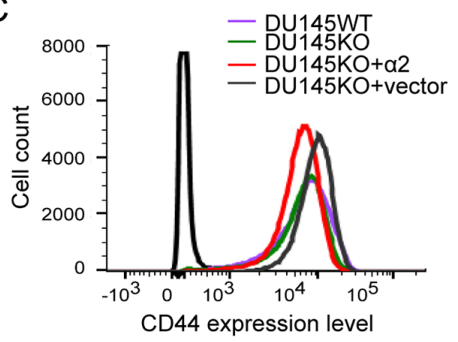

D

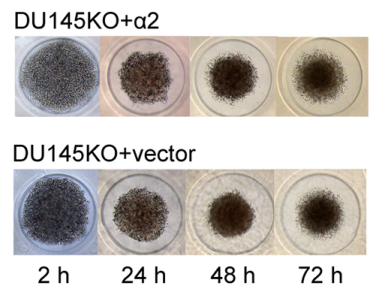

E

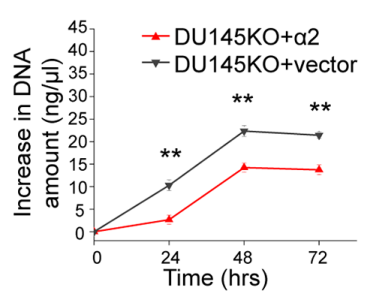

$\mathrm{F}$

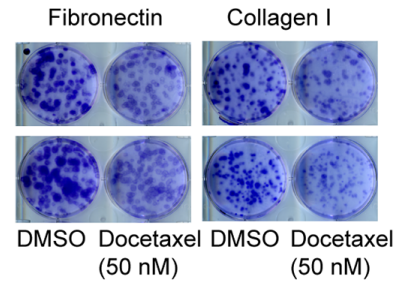

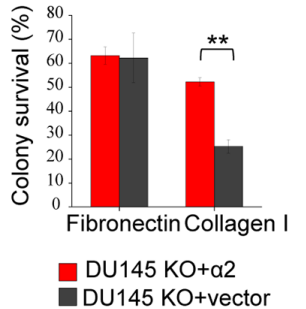

Figure 2: $\alpha 2 \beta 1$ integrin expression decelerates cell proliferation, but promotes resistance to docetaxel. (A) FACS plot showing $\alpha 2$ integrin cell surface expression on DU145WT (purple), DU145KO (green), DU145KO+ 2 (red) and DU145KO+vector (grey) cells. (B) Representative western blot demostrating $\alpha 2$ integrin expression in whole cell lysates of DU145WT, DU145KO, DU145KO+ $\alpha 2$ and DU145KO+vector cells. (C) FACS plot showing surface expression levels of CD44. DU145WT (purple), DU145KO (green), DU145KO+ 22 (red) and in DU145KO+vector (grey) cells. Expression of CD44 is independent from $\alpha 2$ and is not regulated by acquired expression of $\alpha 2$ integrin. (D) Representative images of DU145KO+ 2 and DU145KO+vector cells grown as 3D spheroids up to 72 hours. (E) Quantification of DNA amount to measure the proliferation of DU145KO+ 2 and DU145KO+vector cells in 3D spheroid culture. Data are mean $\pm \operatorname{SEM}(\mathrm{n}=3)$. $^{* *}=\mathrm{P}<0.01$. (F) Representative images of DU145KO+ 2 and DU145KO+vector cells in colony formation and survival assay. Below the quantification of colony survival assay comparing DU145KO+ 2 and DU145KO+vector cells on fibronectin and collagen I. Data are mean $\pm \operatorname{SEM}(n=3) .{ }^{* *}=\mathrm{P}<0.01$. 
level as was measured with their $\alpha 2$ negative counterparts (Figure 4C, 4D).

Thus, we conclude that the effects of $\alpha 2 \beta 1$ expression on proliferation, migration and invasion by prostate cancer cells may be at least partially due to the elevated $\mathrm{p} 38$ phosphorylation.

\section{Integrin $\alpha 2 \beta 1$ regulates cancer progression related genes}

We used RNA sequencing to analyze the putative differences in the gene expression pattern of $\alpha 2$ negative DU145KO+vector cells and $\alpha 2$ positive DU145KO $+\alpha 2$ cells (Figure 5). For that purpose we isolated RNA from cells grown in spheroid cultures. The analyses unveiled several differences (Figure 5A). The top seven overrepresented biological process gene ontology terms among the DE genes from Metascape analysis at http://metascape.org [32] are shown in Figure 5B. Figure $5 \mathrm{C}$ shows top ten genes with the most significant increases or decreases. For further experiments we selected 12 genes based on three criteria: i) difference in expression (up or down regulated) when $\alpha 2$ negative DU145KO+vector cells and $\alpha 2$ positive DU145KO $+\alpha 2$ cells were compared, ii) similar difference in expression when $\alpha 2$ negative DU145KO cells and $\alpha 2$ positive
DU145KO $+\alpha 2$ cell were compared, and iii) preferentially previously described connection to cancer progression. The up regulated genes included: cadherin 5 (CDH5), scavenger receptor class A member 5 (SCARA5), matrix metalloproteinase 1 (MMP1), leucine rich glioma inactivated 1 (LGI1), kinesin family member 26b (KIF26b) and sushi, von Willebrand factor type A, EGF and pentraxin domain containing 1 (SVEP1). The down regulated genes included: chromodomain-helicaseDNA-binding protein 5 (CHD5), von Willebrand factor A domain containing 2 (VWA2), retinol binding protein 1 (RBP1), syndecan 2 (SDC2), plakophilin 1 (PKP1) and spleen associated tyrosine kinase (SYK). The differential expression between $\alpha 2$ positive and $\alpha 2$ negative cells was confirmed by quantitative real time PCR (Figure 5D).

Since MMP1 was remarkably upregulated in $\alpha 2$ positive cells and these cells showed increased mobility, we also tested the effects of a broad spectrum MMP inhibitor, N-Isobutyl-N-(4-methoxyphenylsulfonyl) glycyl hydroxamic acid (NNGH), in migration and invasion assays. The migration of $\mathrm{DU} 145 \mathrm{KO}+\alpha 2$ and DU145WT was significantly reduced in the presence of $1 \mu \mathrm{M}$ NNGH. The invasion was not, however, influenced at the concentration used (Supplementary Figure 5). The results confirmed that MMPs are involved in the mobility of DU145 cells.
A

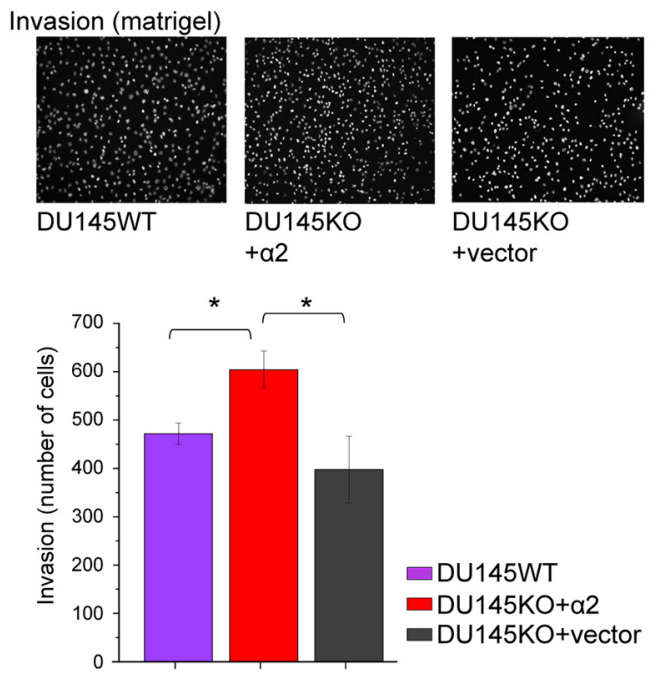

B

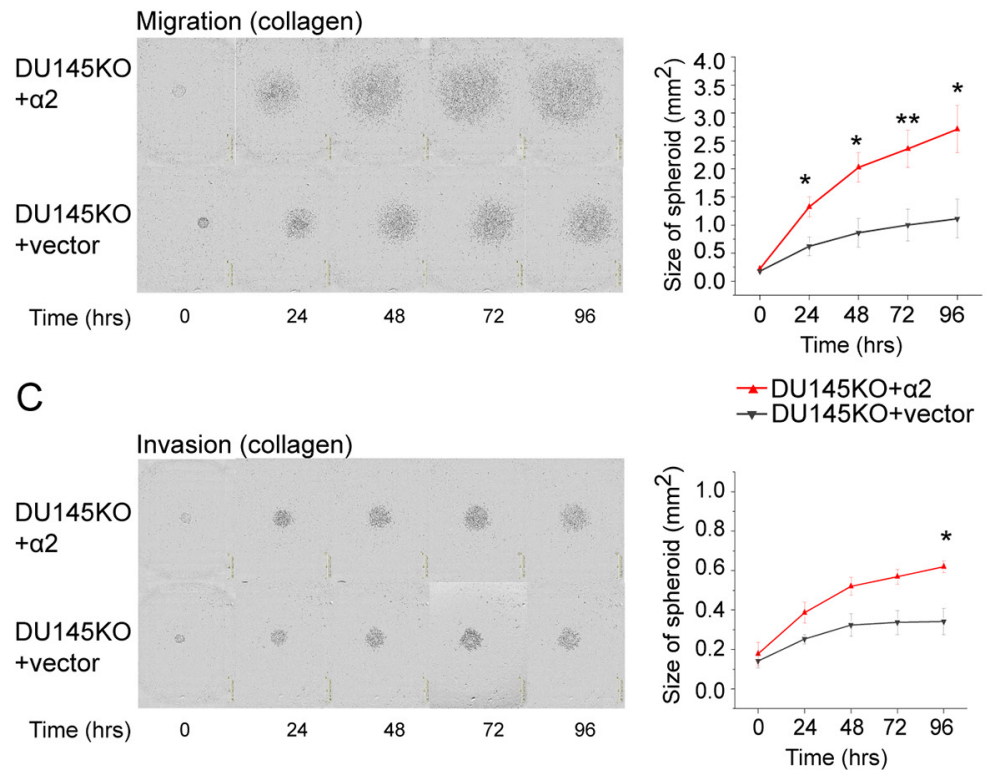

Figure 3: $\alpha 2$ integrin positive DU145 cells are more invasive than $\alpha 2$ negative cells. (A) Representative microscopic images $(10 \mathrm{x})$ of DU145WT, DU145KO+ $\alpha 2$ and DU145KO+vector cells that have invaded through matrigel in the transwell invasion assay. Below, the quantification of the invaded cells. Mean $\pm \operatorname{SEM}(n=5),{ }^{*}=\mathrm{P}<0.05$. One way ANOVA and Tukey HSD post hoc test. (B) Representative images of DU145KO+ $\alpha 2$ and DU145KO+vector cells in migration assay. Cells were allowed to migrate out of spheroids on the collagen I coated surface for 96 hours. The quantitation of cell migration as the area covered by DU145KO+ 2 and DU145KO+vector cells. Data are mean $\pm \operatorname{SEM}(\mathrm{n}=4) .{ }^{*}=\mathrm{P}<0.05 ;{ }^{* * *}=\mathrm{P}<0.01$. (C) Representative images of DU145KO $+\alpha 2$ and DU145KO+vector cells in invasion assay. Cells were allowed to invade out of spheroids into the collagen I gel for 96 hours. The quantitation of cell invasion as the area covered with DU145KO+ 2 and DU145KO+vector cells. Data are mean $\pm \operatorname{SEM}(\mathrm{n}=4) .{ }^{*}=\mathrm{P}<0.05$. 
Despite the fact that the listed changes in gene expression could be linked to the presence of $\alpha 2 \beta 1$ integrin, the result did not answer the question, whether these genes are also directly regulated by $\alpha 2 \beta 1$ binding to its ligand. Therefore, we plated the cells either on collagen I or on fibronectin and analyzed the mRNA levels by qPCR. Ratio of [mRNA level in $\alpha 2^{+}$cells] / [mRNA level in $\alpha 2^{-}$cells] was calculated on both matrices (Figure $5 \mathrm{E})$. The experiment was also repeated using DU145WT ( $\alpha 2$ positive) and DU145KO cells ( $\alpha 2$ negative). The expression of maximally seven out of twelve genes (MMP-1, SVEP1, SYK, VWA2, PKP1, RBP1, SDC2) changed after $\alpha 2 \beta 1$-collagen interaction in the same manner (up or down regulation) than in $\alpha 2$ expressing cells, which leaves open the possibility that $\alpha 2 \beta 1$ may also affect the expression of some genes in a mechanism that is independent of direct ligand binding.

The majority of the twelve selected, $\alpha 2 \beta 1$ integrin associated genes were regulated in a similar manner when PC 3 cells and DU145 cells were compared. When their gene expression patterns were compared after plating on collagen I and fibronectin nine out of twelve genes showed up/down regulation in both cells lines, whereas three genes (SCARA5, SVEP1, SDC2) were differentially regulated (Supplementary Figure 3).

To study the role of p38 activation in the $\alpha 2 \beta 1$ integrin associated changes in gene regulation, we plated DU145KO $+\alpha 2$ cells on collagen or fibronectin in the presence of SB203580 or DMSO (negative control) and measured mRNA levels (at $72 \mathrm{~h}$ ) by real time PCR. In the case of five out of six genes that were up regulated in the presence of $\alpha 2 \beta 1$ integrin (MMP-1, SVEP1, SCARA5, CDH5 and KIF26b), SB203580 reduced mRNA levels below $50 \%$ of control on both collagen (MMP-1 35\%, SVEP1 37\%, SCARA5 40\%, CDH5 43\% and KIF26b $21 \%$ of control) and fibronectin (MMP-1 38\%, SVEP1 $42 \%$, SCARA5 $16 \%$, CDH5 $46 \%$ and KIF $26 \mathrm{~b} 32 \%$ of control). The differences were smaller or not constant in the other seven selected genes. Thus, in most cases the genes, which were positively regulated in the presence of $\alpha 2 \beta 1$ integrin, were also dependent on active p38, whereas no similar association could be seen in genes that were down regulated in the presence of $\alpha 2 \beta 1$ integrin.
A

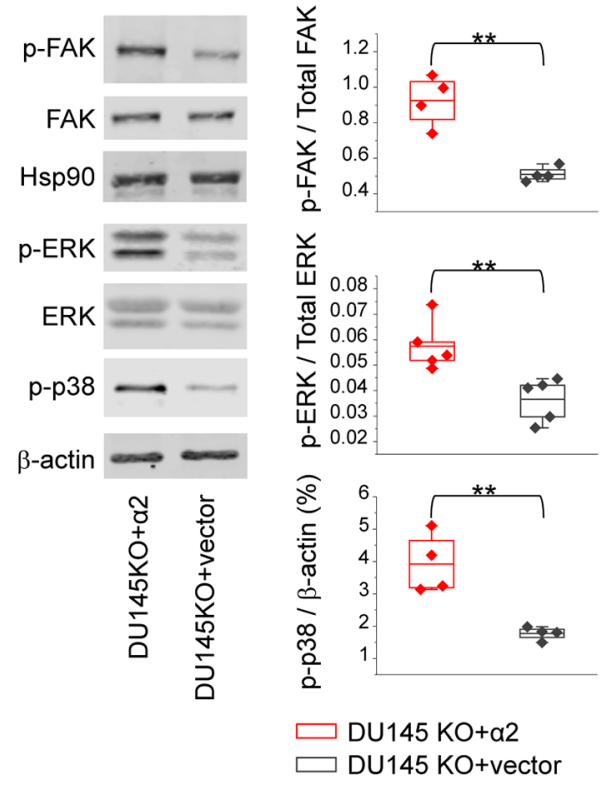

B
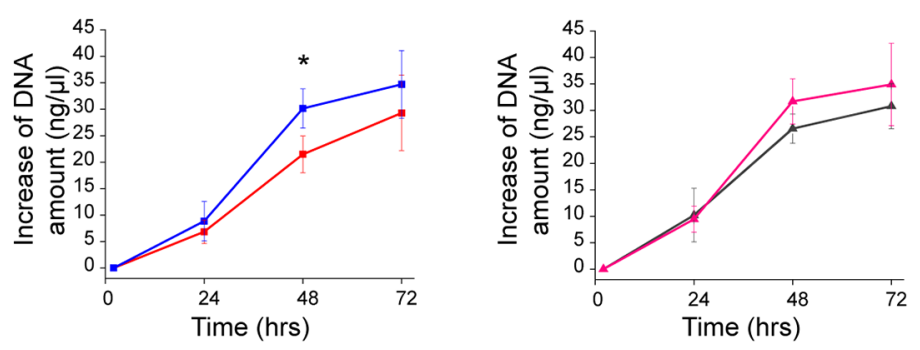

-n- DU145KO+a2 + DMSO

-- DU145KO+a2 + SB203580

- - DU145KO+vector + DMSO

C

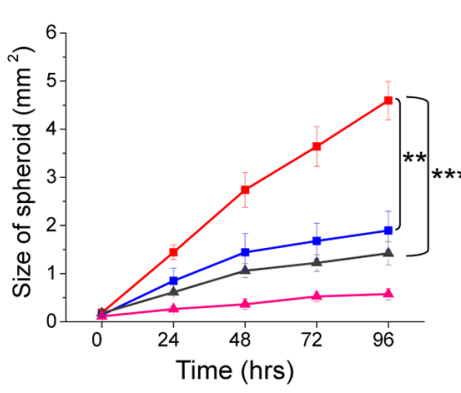

- - DU145KO+vector + SB203580

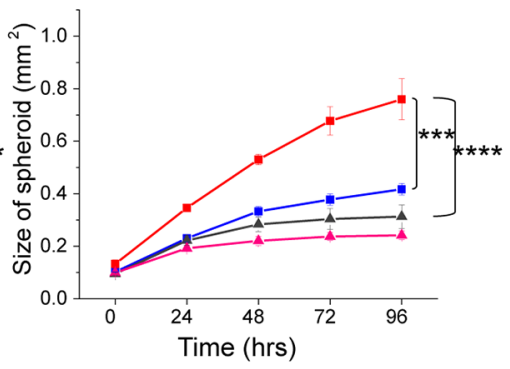

Figure 4: $\alpha 2 \beta 1$ integrin suppresses cell growth and promotes migration and invasion by increasing the phosphorylation of p38 MAPK. (A) Representative western blot indicating that $\alpha 2$ integrin expression on DU145 prostate cancer cells increased phosphorylation of FAK, ERK and p38 MAPK proteins when cells were plated on collagen I coated surface. The quantification of the phosphorylated FAK/ total FAK and phosphorylated ERK/ total ERK is shown; phosphorylation of p38 MAPK is shown as \% of $\beta$-actin (a loading control). Box plot shows data from 4 or 5 independent experiments (dots) and the mean from all experiments \pm SEM. ${ }^{* *}=\mathrm{P}<$ 0.01. Student's $t$-test. (B) p38 MAPK inhibitor SB203580 treatment $(10 \mu \mathrm{g} / \mathrm{ml})$ increased proliferation of DU145 cells. Proliferation of DU145KO+ $\alpha 2$ and DU145KO+vector cells was assessed based on the change in DNA amount in 3D spheroids. Mean $(\mathrm{n}=3) \pm \mathrm{SEM} .{ }^{*}=\mathrm{P}$ $<0.05$. Student's $t$ test. (C) Inhibition of p38 MAPK with SB203580 $(10 \mu \mathrm{g} / \mathrm{ml})$ results significantly decreased migration of DU145KO+ 22 cells on collagen I. Mean $(\mathrm{n}=3) \pm$ SEM. ${ }^{* *}=\mathrm{P}<0.01,{ }^{* * *}=\mathrm{P}<0.001$. One way ANOVA and Tukey HSD post hoc test. (D) Invasion capability of DU145KO $+\alpha 2$ cells into collagen gel decreased significantly when cells were treated with p38 MAPK inhibitor SB203580 $(10 \mu \mathrm{g} / \mathrm{ml})$. Mean $(\mathrm{n}=3) \pm$ SEM. ${ }^{* * *}=\mathrm{P}<0.001$. One way ANOVA and Tukey HSD post hoc test. 


\section{DISCUSSION}

The stem cell theory of cancer suggests that in a tumor very few cells can sustain the malignant process. The idea has important implications: firstly, the cancer stem cell may be the only cell type that gives rise to metastases, and secondly, if anti-cancer therapies are not able to kill the cancer stem cells, the tumor will soon grow back. In prostate cancer, high $\alpha 2 \beta 1$ integrin expression is supposed to be one of the hallmark signs of

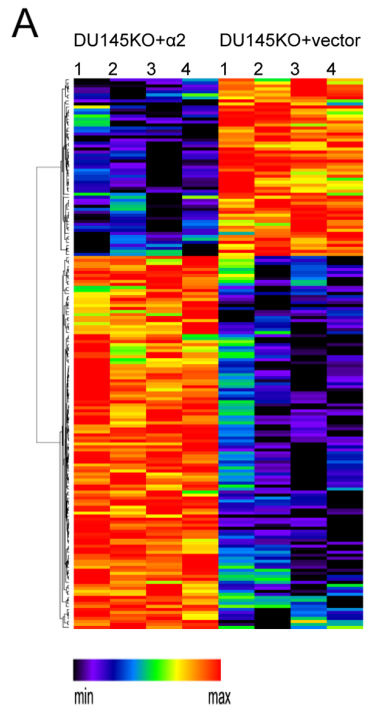

B

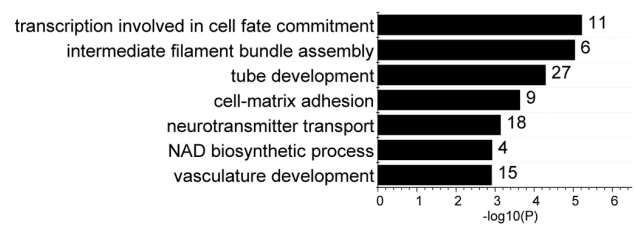

C
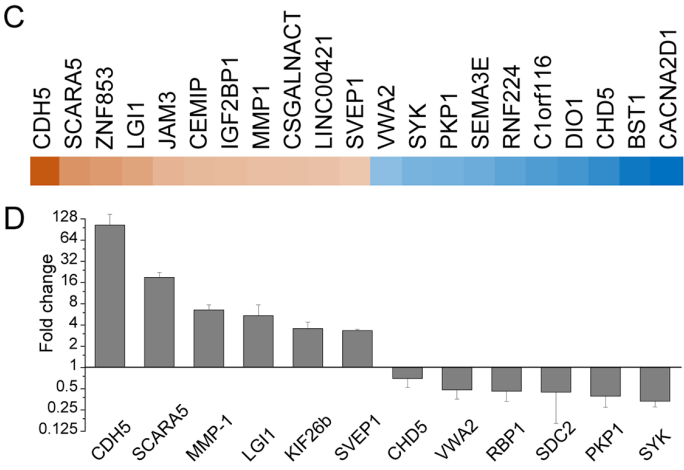

E
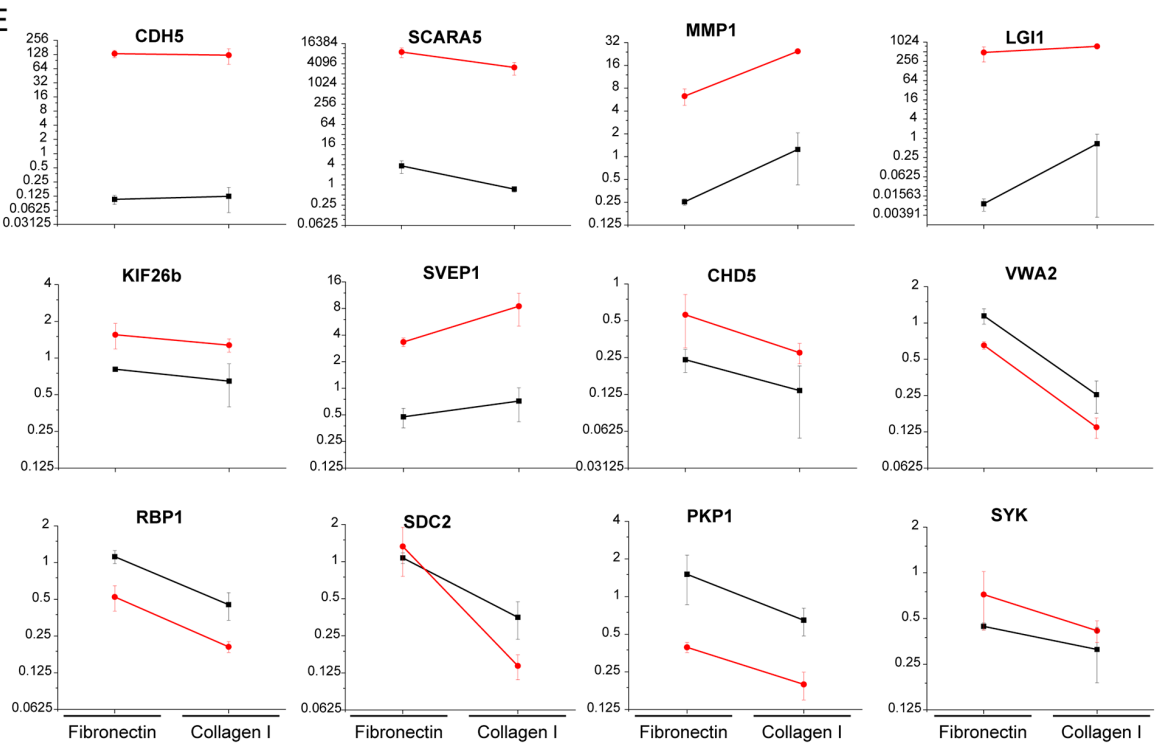

$\rightarrow$ Fold change DU145WT vs. DU145KO

- - Fold change DU145KO+a2 vs. DU145KO+vecto

Figure 5: $\alpha 2 \beta 1$ integrin regulates the expression of cancer associated genes. (A) Differential gene expression pattern of DU145KO+ $\alpha 2$ compared to DU145KO+vector cells. Hierarchical clustering of differentially expressed (DE) genes based on relative gene expression levels detected in RNA sequencing. Red and black colors represent over and under expressed genes, respectively. (B) Differential gene expression in DU145KO+ $\alpha 2$ compared to DU145KO+vector cells has an effect on several biological processes. Significantly overrepresented gene ontology terms based on Metascape analysis. (C) Heatmap of the most up and down regulated genes in DU145KO+ $\alpha 2$ cells when compared to DU145KO+vector cells. Brown and blue colors represent higher and lower expression levels, respectively. (D) Real time PCR analysis of selected, $\alpha 2 \beta 1$ integrin associated genes, in DU145KO+ $\alpha 2$ and in DU145KO+vector cells grown as 3D spheroids. Difference is shown as the fold change of relative mRNA expression level in DU145KO+ 2 compared to DU145KO+vector expression level. Data are mean $(\mathrm{n}=3) \pm$ SEM. (E) Effect of cell adhesion to extracellular matrix on the selected $\alpha 2$ integrin associated genes. Cells were grown either on collagen I or on fibronectin for $72 \mathrm{~h}$, after that relative mRNA levels of selected genes was analyzed by qPCR. Each data point represents the ratio of mRNA levels in $\alpha 2$ positive / $\alpha 2$ negative cells. Both, DU145KO+ $\alpha 2$ / DU145KO+vector (red line) and DU145WT / DU145KO (black line) comparisons were made. Data are mean $(n=3) \pm$ SEM. 
the stem cell phenotype [11]. During the progression of the disease $\alpha 2 \beta 1$ positive cells are getting more and more rare $[14,15]$, but still the collagen receptor may play an important role in metastasis [16-18]. Our experiments were planned to solve this controversy and unveil the function of $\alpha 2 \beta 1$ integrin in prostate cancer cells at molecular level.

Using DU145 cell line we showed that the population of cells, which survived the docetaxel treatment, expressed slightly more $\alpha 2 \beta 1$ integrin than non-treated DU145 cells. Also previous studies have shown that chemoradiotherapy resistant DU145 cells have elevated levels of two other stem cell markers, namely CD44 and CD133 [33]. Furthermore, CD44 and $\alpha 2 \beta 1$ positive DU145 cells are more tumorigenic than the cells that have lower expression levels of these marker proteins [34]. Here, we used flow cytometry to separate $\alpha 2 \beta 1^{\text {High }}$ and $\alpha 2 \beta 1^{\text {Low }}$ DU145 cell subpopulations and demonstrated the slower proliferation rate of the $\alpha 2 \beta 1^{\text {High }}$ population. Increased survival during paclitaxel treatment and slow proliferation may be linked to each other since paclitaxel affects cell division and kills actively growing cells. Previously, up regulation of phosphatidyl inositol3-kinase/Akt and MAPK pathways have been linked to the resistance of microtubule-targeting drugs in prostate cancer [35]. Interestingly, both pathways can also be regulated by $\alpha 2 \beta 1$ integrin $[22,36]$.

The observations based on the comparison of $\alpha 2 \beta 1^{\text {High }}$ and $\alpha 2 \beta 1^{\text {Low }}$ subpopulations demonstrated a link between the collagen receptor expression and the stem cell like phenotype. However, it remained still unknown, whether $\alpha 2 \beta 1$ directly participates in the process that dictates the stem cell like behavior. Therefore, we used Crispr/Cas9 technology to knockout $\alpha 2$ integrin in DU145 cells. To create two cell lines that could be compared to each other in an appropriate manner, we transfected DU145KO cells either with $\alpha 2$ integrin cDNA or with empty vector. We choose to study the cellular functions in spheroids instead of monolayer cultures since pronounced $\alpha 2 \beta 1$ integrin signaling may be dependent on the $3 \mathrm{D}$ environment [1]. Our results indicated that $\alpha 2 \beta 1$ integrin decelerates prostate cancer cell proliferation. Importantly, this observation may explain the decrease in the number of $\alpha 2 \beta 1$ positive cells during prostate cancer progression. Still $\alpha 2 \beta 1$ positive cells migrated and invaded significantly more effectively than their $\alpha 2 \beta 1$ negative counterparts. Thus the presence of this receptor may give remarkable advantage in cancer dissemination related processes. This may explain the presence of $\alpha 2 \beta 1$ integrin in metastatic prostate cancer cells and stress the role of $\alpha 2 \beta 1$ positive cells especially in the early dissemination.

Our data also indicated that $\alpha 2 \beta 1$ integrin regulates several cancer associated genes. A large increase was seen in cadherin 5 (CDH5, vascular endothelial cadherin) that plays an important role in homotypic cell-cell adhesion among epithelial cells. CDH5 is a marker of poor survival in human gastric cancer [37]. Seemingly paradoxically, $\alpha 2 \beta 1$ expression also increased the mRNA levels of two tumor suppressors, namely SCARA5 (Scavenger receptor class A, member 5) and LGI1 (Leucine-rich, glioma inactivated 1). The up regulation of these anti proliferation genes is, however, in accordance with the fact that $\alpha 2 \beta 1$ integrin expression also suppressed cell proliferation. Concomitantly $\alpha 2 \beta 1$ down regulated the expression of two other tumor suppressors, namely PKP1 (plakophilin 1) and CDH5 (chromodomain helicase DNA binding protein 5). Largest down regulation was seen in syndecan 2 expression. Interestingly, syndecan 2 is strongly up regulated in prostate cancers with high Gleason score [38]. In Gleason 3-5 prostate cancers $\alpha 2 \beta 1$ integrin is significantly decreased [15], suggesting that the expression levels of $\alpha 2 \beta 1$ and syndecan 2 may be linked in vivo, too.

In prostate cancer cells, MMP-1 may be a critical, invasion promoting factor [39]. Here, in accordance with the observation that $\alpha 2 \beta 1$ promotes cell invasion, it remarkably up regulated the expression of MMP-1. Our previous studies have also indicated the association of $\alpha 2 \beta 1$ integrin and MMP-1 expression in other cell types [40].

In maximally 7 out of 12 cases the genes that were up or down regulated in $\alpha 2 \beta 1$ positive cells, when compared to their $\alpha 2 \beta 1$ negative counterparts, were also regulated after $\alpha 2 \beta 1-$ collagen interaction. However, in many experiments $\alpha 2 \beta 1$ related effect was similar when cells were plated either on collagen or fibronectin. Thus, we cannot exclude the possibility that $\alpha 2 \beta 1$ may also have ligand independent functions. Ligand independent integrin signaling has been shown to occur in some experimental models [41], but in general these mechanisms are poorly known.

We also suggest that the activation of p38 MAPK by $\alpha 2 \beta 1$ integrin is one of the major pathways suppressing proliferation and activating invasion. Previous studies have shown that $\mathrm{p} 38$ often acts as a protumorigenic factor $[42,43]$. Based on histological staining of human prostate tumors p38 MAPK expression has a significant, positive correlation with carcinogenesis, cancer progression and patient survival [44]. Regulation of cell locomotion by $\mathrm{p} 38$ has been documented in many cell types [45], including DU145 cells [46]. Here, MMP-1 expression was dependent on p38 activity, which further stresses the role of this signaling pathway in the $\alpha 2 \beta 1$ integrin dependent invasion.

To conclude, our results suggest that $\alpha 2 \beta 1^{\text {High }}$ cells have stem cell like properties and these cells may play an important role in the sustenance of prostate cancer and in the processes leading to dissemination. Thus, this cell type should be the primary target when new therapies are developed. 


\section{MATERIALS AND METHODS}

\section{Cell lines}

The human prostate cancer cell-lines DU145 and PC3 were obtained directly from ATCC. DU145WT and PC 3 cells have endogenous expression of $\alpha 2$ integrin. To create an $\alpha 2$ negative cell line genome editing method was applied by transfecting DU145 cells with all-in-one Crispr/ Cas9 vector (Sigma, HS0000253951 gRNA sequence: GTTACTGGTTGGTTCACCCTGG), transfected cells were selected based on the expression of GFP, allowed to grow and checked for $\alpha 2$ integrin surface expression. The cells that had been transfected with Crispr/Cas9 vector and successful ITGA2 knockout had taken place, were named as DU145KO. A smaller population of cells with Crispr/ Cas9 vector, but still $\alpha 2$ integrin expression, was sorted out by flow cytometer. DU145KO cells were stably transfected either with pAWneo2 vector carrying $\alpha 2$ integrin cDNA [47] to regenerate $\alpha 2$ positive cell line (DU145KO $+\alpha 2$ cells) or with empty pAWneo 2 vector to create a proper a2 negative control cell line (DU145KO+vector). $\mathrm{DU} 145 \mathrm{KO}+\alpha 2$ and DU145KO+vector cells were grown in the presence of $0.25 \mathrm{mg} / \mathrm{ml}$ geneticin (GIBCO). All cells were maintained in RPMI1640 medium (Lonza), supplemented with $10 \%$ fetal calf serum (FCS, Biowest), 2 $\mathrm{mM}$ Ultraglutamate, $100 \mathrm{U} / \mathrm{ml}$ penicillin and streptomycin (Lonza). In the indicated experiments also serumfree keratinocyte medium (KSF) with $5 \mathrm{ng} / \mathrm{ml}$ human recombinant EGF, $50 \mu \mathrm{g} / \mathrm{ml}$ bovine pituitary extract (all from Gibco), supplemented with $2 \mathrm{ng} / \mathrm{ml}$ recombinant human leukemia inhibitory factor and $2 \mathrm{ng} / \mathrm{ml} \mathrm{stem} \mathrm{cell}$ factor (Sigma Aldrich) was used. Cells were routinely screened with MycoAlert ${ }^{\mathrm{TM}}$ PLUS Mycoplasma detection kit (Lonza).

\section{Spheroid cultures}

Spheroids were made in micro-molds according to the manufacturer's instructions (3D Petri Dish, MicroTissues) with $2.8 \times 10^{5}$ cells in one mold ( 8000 cells in one spheroid). Spheroids were grown in RPMI 1640 serum-free (SF) medium.

\section{RNA extraction}

After 72 hours, total RNA was extracted from the cells cultured in spheroids by using NucleoSpin RNA (Macherey-Nagel) kit according to the manufacturer's instructions. The quality and quantity of the RNA was checked using Nanodrop ND-2000 spectrophotometer (Thermo Scientific).

\section{RNA sequencing}

The samples were prepared for the sequencing using Illumina TruSeq Stranded mRNA Sample Preparation
Kit and $0.9 \mu \mathrm{g}$ of high-quality RNA from each sample was analyzed with $\mathrm{HiSeq}^{\circledR} 2500$ Sequencing System (Illumina) using single-end sequencing chemistry and $50 \mathrm{bp}$ read length. Total of 4 samples 4 independent biological replicates were analyzed and run in two lanes. The reads obtained from the instrument were base called using the instrument manufacturer's Bcl2fastq version 1.8.4 base calling software. The read alignment was performed in two stages: first, the reads were aligned against the reference genome (human hg38, downloaded from Illumina iGenomes web site) using TopHat version 2.1.0 [48]. Then the reads were associated with known genes and the number of reads associated with each gene was counted using subreads package (v. 1.5.0) [49]. Only uniquely aligned reads were used for the downstream analysis.

The gene-wise read counts were normalized using the TMM normalization method of the edgeR R/ Bioconductor package. For statistical testing the data were further transformed using the voom approach in the limma package. $\mathrm{R}$ package Limma [50] was used for performing the statistical testing between the groups. The gene was determined as differentially expressed (DE) if the fold change was $>2$ between comparison groups. The DE genes were ranked as follows: first the genes inside each comparison were ranked independently based on p-values (increasing order) and absolute fold changes (decreasing order). Next the average ranks for these two were calculated. As these values do not follow the original value range, these average ranks were further ranked again to get the ranks from 1 to the number of genes, rank of 1 meaning the highest possible rank (most differentially expressed gene based both on p-value and fold change). In tie situations, the order was randomized.

The sequencing data have been deposited in NCBI's Gene Expression Omnibus and are accessible through GEO Series accession number GSE111507 (https://www. ncbi.nlm.nih.gov/geo/query/acc.cgi?acc=GSE111507).

\section{Matrigel transwell invasion assay}

The ability of DU145 and PC3 cells to invade through Matrigel was examined using Matrigel coated invasion chambers (\#354480, Corning) according to the manufacturer's instructions. Samples were prepared in triplicates, $1 \times 10^{5}$ cells were seeded into the top chamber of 24-well insert in $0.5 \mathrm{ml} 0.1 \%$ BSA-containing RPMI $\mathrm{SF}$ media. Medium with $10 \%$ FCS was used as a chemoattractant in the bottom chamber. After 24 hours, residual cells on the top surface of insert were removed, membranes were fixed with cold methanol and nuclei were stained with DAPI. Nuclei were imaged from 9 fields of each membrane, and counted with ImageJ. Average nuclei count for each cell type was obtained, normality of the data was tested with the Shapiro-Wilk test and statistical significances were obtained by comparing the average 
nuclei counts with one-way ANOVA test and pairwise comparisons were made with the Tukey HSD post hoc test.

\section{Out of spheroid cell migration on and invasion through collagen I}

The role of $\alpha 2$ integrin in the DU145 cell migration on collagen I or invasion through 3D collagen I gel was studied by placing spheroids as triplicates on collagen I coated 96 -well plates. When invasion was tested a collagen I gel $(2.0 \mathrm{mg} / \mathrm{ml}$ bovine skin collagen I, Nutragen, Advanced BioMatrix; $4 \mathrm{mM}$ Tris- $\mathrm{HCl}, \mathrm{pH} 7.3$, and $20 \mathrm{mM} \mathrm{NaOH}$ in serum-free RPMI) was layered on the top of the spheroids. KSF medium (described above) was placed above the collagen gel. Spheroids were allowed to migrate or invade for 96 hours and imaged every 24 hours with IncuCyte ZOOM System (Essen Bioscience). ImageJ was used to detect the area covered with cells. Mean cell covered areas from four independent experiments were calculated.

To study the effects of p38 inhibitor (SB203580) and MMP inhibitor NNGH the migration and invasion assays were modified in a way that medium added on top of spheroid or on top of collagen I gel contained DMSO in control $(0.05 \%$ or $0.38 \%)$ or respectively $10 \mu \mathrm{M} \mathrm{SB} 2035$ or $1 \mu \mathrm{M}$ NNGH.

\section{Cell survival assays}

DU145 and PC3 cells were seeded on collagen I (from bovine skin, PureCol ${ }^{\circledR}$, Advanced BioMatrix) or fibronectin (from human plasma, Sigma Aldrich) coated cell culture dishes with KSF medium, allowed to grow for $24 \mathrm{~h}$, then exposed to $50 \mathrm{nM}$ docetaxel (Sigma Aldrich) or for controls with $0.025 \%$ of DMSO in KSF medium for $24 \mathrm{~h}$. The surviving cells were collected for flow cytometric analysis.

\section{Cell proliferation in 2D and 3D cultures}

Cell proliferation in $2 \mathrm{D}$ monolayer cultures was assayed by estimating the cell numbers using WST-8 Assay (Dojindo Molecular Technologies) according to the manufacturer's instructions. The cell proliferation in $3 \mathrm{D}$ cultures was measured by extraction of genomic DNA from spheroids at 0, 24, 48 and 72 hours with NucleoSpin ${ }^{\circledR}$ Tissue kit (Macherey-Nagel). The concentration of DNA was measured by Qubit ${ }^{\mathrm{TM}}$ dsDNA HS Assay Kit (Thermo Fisher Scientific).

To study the effects of p38 inhibitor (SB203580) on proliferation, the media around the agarose micro mold included $0.05 \%$ of DMSO for control or $10 \mu \mathrm{M}$ SB2035.

\section{Real-time PCR analysis}

For mRNA expression analysis cells were grown either as spheroids or on collagen I or fibronectin coated cell culture dishes for 72 hours in serum-free RPMI 1640.
cDNA was prepared from $1 \mu \mathrm{g}$ of RNA with SensiFAST cDNA Synthesis Kit according to the manufacturer's instructions (Bioline). Primers, designed in house, and probes (Universal ProbeLibrary (Roche)) are listed in Supplementary Table 1. qPCR was performed using a QuantStudio 12K Flex Real-Time PCR System (Thermo Fisher) at the Finnish Functional Genomics Centre (Turku Centre for Biotechnology). PCR reactions were performed in triplicates in a 96-well plate and a $10 \mu \mathrm{l}$ final reaction volume consisting of $5 \mu \mathrm{l}$ of ABI TaqMan Universal Master Mix II (Applied Biosystems), $100 \mathrm{nM}$ TaqMan probe, $300 \mathrm{nM}$ of each primer and $2 \mu \mathrm{l}$ of cDNA sample. The PCR reaction conditions were $95{ }^{\circ} \mathrm{C}$ for 10 min, followed by 45 cycles of $95^{\circ} \mathrm{C}$ for $15 \mathrm{~s}$ and $60^{\circ} \mathrm{C}$ for $1 \mathrm{~min}$. Differences in gene expression levels between cell types were calculated using the cycle threshold $\left(\mathrm{C}_{\mathrm{T}}\right)$ values, normalized to the $\mathrm{C}_{\mathrm{T}}$ values of GAPDH and fold changes were calculated based on formula $2^{-\Delta \Delta C t}[51]$.

\section{Flow cytometry and cell sorting}

For the analysis of $\alpha 2$ integrin surface expression levels, DU145 and PC3 cells were detached with trypsin, washed and subsequently cells were incubated in a blocking buffer (1\% FCS in PBS) on ice for 30 min to inhibit unspecific binding of antibodies. Cells were centrifuged and incubated with primary antibody (Supplementary Table 2) for $1 \mathrm{~h}$ with gentle agitation at $+4^{\circ} \mathrm{C}$, washed twice with PBS and incubated for $45 \mathrm{~min}$ at $+4{ }^{\circ} \mathrm{C}$ with $7.5 \mu \mathrm{g} / \mathrm{ml}$ anti-mouse FITC-conjugated secondary antibody (A16167, Life Technologies). For CD44 surface expression level detection cells were treated with FITC-conjugated antihuman CD44 antibody (ab19622, Abcam) for $1 \mathrm{~h}$ at $+4^{\circ} \mathrm{C}$. As controls, IgG control or only secondary antibody stained samples were used. Integrin $\alpha 2$ and CD44 cell surface levels were measured immediately after staining procedure with FACSCalibur or Fortessa (BD Biosciences) and results were analyzed with FlowJo program (FlowJo, LLC).

For sorting cells into $\alpha 2 \beta 1^{\text {High }}$ and $\alpha 2 \beta 1^{\text {Low }}$ subpopulations the same staining procedure was performed in the larger scale set up (from $25 \times 10^{6}$ cells). $20 \%$ of cells with lowest and $20 \%$ of cells with highest expression levels of $\alpha 2$ integrin were gated and sorted out with FACSaria Ilu Cell Sorter.

The docetaxel treated and normal DU145 cells were analyzed for studying the arresting of cell cycle. Briefly, the cells were seeded as explained in Cell Survival Assay section. Followed by cell staining with propidium iodide (prepared in PBS $1 \mathrm{x} ; 40 \mathrm{mM}$ sodium citrate, $0.3 \%$ Triton $\mathrm{X}-100$, and $50 \mu \mathrm{g} / \mathrm{ml}$ propidium iodide) and DNA contents of stained nuclei were analyzed by using LSRFortessa flow cytometer, results were analyzed using the FlowJo program.

\section{Western blots}

Cells were lysed on ice into cold lysis buffer $(10 \mathrm{mM}$ Tris-HCl, $\mathrm{pH} 7.4$, Triton X-100, supplemented with protease 
inhibitors $1 \mathrm{mM}$ EDTA, $10 \mathrm{mM} \mathrm{NaF}, 10 \mu \mathrm{g} / \mathrm{ml}$ Aprotin, $10 \mu \mathrm{g} /$ $\mathrm{ml}$ Leupeptin, $1 \mathrm{mM} \mathrm{Na} \mathrm{VO}_{4}, 2 \mathrm{mM}$ PMSF, and $10 \mathrm{mM}$ $\mathrm{Na}_{4} \mathrm{P}_{2} \mathrm{O}_{7}$ ). $35 \mu \mathrm{g}$ of protein in Laemmli SDS-PAGE sample buffer was loaded on gels, and proteins were separated with SDS-PAGE electrophoresis. Proteins were transferred to nitrocellulose membrane, followed by incubation in blocking buffer ( $5 \%$ milk powder, $1 \%$ BSA, TBST). The membranes were incubated with primary antibodies (Supplementary Table 2) overnight at $+4^{\circ} \mathrm{C}$, followed by washing in TBST and incubation with secondary antibody (926-32213, LICOR). Protein loading was controlled with house-keeping proteins $\beta$-actin and Hsp90.

\section{Colony survival assay}

6-well plates were coated either with fibronectin or collagen I $\left(5 \mu \mathrm{g} / \mathrm{cm}^{2}\right)$ for 24 hours at $+4^{\circ} \mathrm{C}$, and blocked with $1 \% \mathrm{BSA}-\mathrm{PBS}$ for 1 hours at $37^{\circ} \mathrm{C}$. DU145 cells were seeded on the coated plates, 200 cells per well. The cells were grown for 10 days in 10\% RPMI, after which the medium was changed into KSF medium. On the following day, $50 \mathrm{nM}$ docetaxel or DMSO (as a control) was added to the cells and the colonies were allowed to grow for additional 24 hours. The colonies were fixed with 4\% PFA for $15 \mathrm{~min}$, stained with $0.5 \%$ crystal violet in $10 \%$ ethanol for $15 \mathrm{~min}$, and washed twice with PBS to remove excess stain. The average colony area percentage was calculated using the colony area ImageJ plugin [52].

\section{Abbreviations}

MMP-1: matrix metalloproteinase-1; MAPK: mitogen activated protein kinase; ECM: extracellular matrix; FAK: focal adhesion kinase; KSF: keratinocyte serum-free medium; EGF: epidermal growth factor; CDH5: cadherin 5; SCARA5: scavenger receptor class A member 5; LGI1: leucine rich glioma inactivated 1; KIF26b: kinesin family member 26b; SVEP1: sushi, von Willebrand factor type A, EGF and pentraxin domain containing 1; CHD5: chromodomain-helicase-DNAbinding protein 5; VWA2: von Willebrand factor A domain containing 2; RBP1: retinol binding protein 1; SDC2:syndecan 2; PKP1: plakophilin 1; SYK: spleen associated tyrosine kinase; WT: wild type.

\section{Author contributions}

$\mathrm{MO}$ and $\mathrm{JH}$ designed the research. MO, MP, PR, EA, $\mathrm{JJ}, \mathrm{NV}$, and ES performed the experiments. MO, PR and JH collected, analyzed and interpreted the data and wrote the manuscript. All authors have revised the manuscript.

\section{ACKNOWLEDGMENTS}

We thank the Academy of Finland, the Sigrid Jusélius Foundation, the Finnish Cancer Associations, and the 7th framework program of European Union (Marie Curie INT, CAFFEIN). Maria Tuominen is acknowledged for excellent technical assistance.

\section{CONFLICTS OF INTEREST}

The authors disclose no potential conflicts of interest.

\section{REFERENCES}

1. Heino J. Cellular signaling by collagen-binding integrins. Adv Exp Med Biol. 2014; 819:143-55.

2. Sriramarao P, Mendler M, Bourdon MA. Endothelial cell attachment and spreading on human tenascin is mediated by alpha 2 beta 1 and alpha v beta 3 integrins. J Cell Sci. 1993; 105:1001-12.

3. Chan BM, Hemler ME. Multiple functional forms of the integrin VLA-2 can be derived from a single alpha 2 cDNA clone: interconversion of forms induced by an anti-beta 1 antibody. J Cell Biol. 1993; 120:537-43.

4. Bix G, Fu J, Gonzalez EM, Macro L, Barker A, Campbell S, Zutter MM, Santoro SA, Kim JK, Höök M, Reed CC, Iozzo RV. Endorepellin causes endothelial cell disassembly of actin cytoskeleton and focal adhesions through alpha2beta1 integrin. J Cell Biol. 2004; 166:97-109.

5. Guidetti G, Bertoni A, Viola M, Tira E, Balduini C, Torti M. The small proteoglycan decorin supports adhesion and activation of human platelets. Blood. 2002; 100:1707-14.

6. Chen J, Diacovo TG, Grenache DG, Santoro SA, Zutter MM. The alpha(2) integrin subunit-deficient mouse: a multifaceted phenotype including defects of branching morphogenesis and hemostasis. Am J Pathol. 2002; 161:337-44.

7. Holtkötter O, Nieswandt B, Smyth N, Müller W, Hafner M, Schulte V, Krieg T, Eckes B. Integrin alpha 2-deficient mice develop normally, are fertile, but display partially defective platelet interaction with collagen. J Biol Chem. 2002; 277:10789-94.

8. Edelson BT, Li Z, Pappan LK, Zutter MM. Mast cellmediated inflammatory responses require the alpha 2 beta 1 integrin. Blood. 2004; 103:2214-20.

9. Grenache DG, Zhang Z, Wells LE, Santoro SA, Davidson JM, Zutter MM. Wound healing in the alpha2beta1 integrin-deficient mouse: altered keratinocyte biology and dysregulated matrix metalloproteinase expression. J Invest Dermatol. 2007; 127:455-66.

10. Zweers MC, Davidson JM, Pozzi A, Hallinger R, Janz K, Quondamatteo F, Leutgeb B, Krieg T, Eckes B. Integrin alpha2beta 1 is required for regulation of murine wound angiogenesis but is dispensable for reepithelialization. $\mathrm{J}$ Invest Dermatol. 2007;127:467-78.

11. Collins AT, Habib FK, Maitland NJ, Neal DE. Identification and isolation of human prostate epithelial stem cells based 
on alpha(2)beta(1)-integrin expression. J Cell Sci. 2001; 114:3865-72.

12. Richardson GD, Robson CN, Lang SH, Neal DE, Maitland NJ, Collins AT. CD133, a novel marker for human prostatic epithelial stem cells. J Cell Sci. 2004; 117:3539-45.

13. Goldstein AS, Lawson DA, Cheng D, Sun W, Garraway IP, Witte ON. Trop2 identifies a subpopulation of murine and human prostate basal cells with stem cell characteristics. Proc Natl Acad Sci U S A. 2008; 105:20882-7.

14. Bonkhoff H, Stein U, Remberger K. Differential expression of alpha 6 and alpha 2 very late antigen integrins in the normal, hyperplastic, and neoplastic prostate: simultaneous demonstration of cell surface receptors and their extracellular ligands. Hum Pathol. 1993; 24:243-8.

15. Mirtti T, Nylund C, Lehtonen J, Hiekkanen H, Nissinen L, Kallajoki M, Alanen K, Gullberg D, Heino J. Regulation of prostate cell collagen receptors by malignant transformation. Int J Cancer. 2006; 118:889-98.

16. Kostenuik PJ, Sanchez-Sweatman O, Orr FW, Singh G. Bone cell matrix promotes the adhesion of human prostatic carcinoma cells via the alpha 2 beta 1 integrin. Clin Exp Metastasis. 1996; 14:19-26.

17. Lang SH, Clarke NW, George NJ, Testa NG. Primary prostatic epithelial cell binding to human bone marrow stroma and the role of alpha2beta1 integrin. Clin Exp Metastasis. 1997; 15:218-27.

18. Sottnik JL, Daignault-Newton S, Zhang X, Morrissey C, Hussain MH, Keller ET, Hall CL. Integrin alpha2beta 1 ( $\alpha 2 \beta 1)$ promotes prostate cancer skeletal metastasis. Clin Exp Metastasis. 2013; 30:569-78.

19. Nagakawa O, Akashi T, Hayakawa Y, Junicho A, Koizumi K, Fujiuchi Y, Furuya Y, Matsuda T, Fuse H, Saiki I. Differential expression of integrin subunits in DU-145/AR prostate cancer cells. Oncol Rep. 2004; 12:837-41.

20. Ivaska J, Reunanen H, Westermarck J, Koivisto L, Kähäri VM, Heino J. Integrin alpha2beta1 mediates isoformspecific activation of p38 and upregulation of collagen gene transcription by a mechanism involving the alpha2 cytoplasmic tail. J Cell Biol. 1999; 147:401-16.

21. Klekotka PA, Santoro SA, Ho A, Dowdy SF, Zutter MM. Mammary epithelial cell-cycle progression via the alpha(2)beta(1) integrin: unique and synergistic roles of the alpha(2) cytoplasmic domain. Am J Pathol. 2001; 159:983-92.

22. Klekotka PA, Santoro SA, Wang H, Zutter MM. Specific residues within the alpha 2 integrin subunit cytoplasmic domain regulate migration and cell cycle progression via distinct MAPK pathways. J Biol Chem. 2001;276:32353-61.

23. Klekotka PA, Santoro SA, Zutter MM. alpha 2 integrin subunit cytoplasmic domain-dependent cellular migration requires p38 MAPK. J Biol Chem. 2001; 276:9503-11.

24. Koyama H, Raines EW, Bornfeldt KE, Roberts JM, Ross R. Fibrillar collagen inhibits arterial smooth muscle proliferation through regulation of $\mathrm{Cdk} 2$ inhibitors. Cell. 1996; 87:1069-78.

25. Henriet P, Zhong ZD, Brooks PC, Weinberg KI, DeClerck YA. Contact with fibrillar collagen inhibits melanoma cell proliferation by up-regulating p27KIP1. Proc Natl Acad Sci U S A. 2000; 97:10026-31.

26. Ivaska J, Heino J. Cooperation between integrins and growth factor receptors in signaling and endocytosis. Annu Rev Cell Dev Biol. 2011; 27:291-320.

27. Hollenbeck ST, Itoh H, Louie O, Faries PL, Liu B, Kent KC. Type I collagen synergistically enhances PDGF-induced smooth muscle cell proliferation through pp60src-dependent crosstalk between the alpha2beta1 integrin and PDGFbeta receptor. Biochem Biophys Res Commun. 2004; 325:328-37.

28. Ning Y, Zeineldin R, Liu Y, Rosenberg M, Stack MS, Hudson LG. Down-regulation of integrin alpha2 surface expression by mutant epidermal growth factor receptor (EGFRvIII) induces aberrant cell spreading and focal adhesion formation. Cancer Res. 2005; 65:9280-6.

29. McCall-Culbreath KD, Li Z, Zutter MM. Crosstalk between the alpha2beta1 integrin and c-met/HGF-R regulates innate immunity. Blood. 2008; 111:3562-70.

30. Ziaee S, Chung LW. Induction of integrin $\alpha 2$ in a highly bone metastatic human prostate cancer cell line: roles of RANKL and AR under three-dimensional suspension culture. Mol Cancer. 2014; 13:208.

31. Van Slambrouck S, Jenkins AR, Romero AE, Steelant WF. Reorganization of the integrin alpha2 subunit controls cell adhesion and cancer cell invasion in prostate cancer. Int $\mathrm{J}$ Oncol. 2009; 34:1717-26.

32. Tripathi S, Pohl MO, Zhou Y, Rodriguez-Frandsen A, Wang G, Stein DA, Moulton HM, DeJesus P, Che J, Mulder LC, Yángüez E, Andenmatten D, Pache L, et al. Meta- and orthogonal integration of influenza "OMICs" data defines a role for UBR4 in virus budding. Cell Host Microbe. 2015; 18:723-35.

33. Wang L, Huang X, Zheng X, Wang X, Li S, Zhang L, Yang $\mathrm{Z}$, Xia Z. Enrichment of prostate cancer stem-like cells from human prostate cancer cell lines by culture in serum-free medium and chemoradiotherapy. Int J Biol Sci. 2013; 9:472-9.

34. Patrawala L, Calhoun-Davis T, Schneider-Broussard R, Tang DG. Hierarchical organization of prostate cancer cells in xenograft tumors: the CD44+alpha2beta1+ cell population is enriched in tumor-initiating cells. Cancer Res. 2007; 67:6796-805.

35. Liu Z, Zhu G, Getzenberg RH, Veltri RW. The upregulation of PI3K/Akt and MAP kinase pathways is associated with resistance of microtubule-targeting drugs in prostate vancer. J Cell Biochem. 2015; 116:1341-9.

36. Ivaska J, Nissinen L, Immonen N, Eriksson JE, Kähäri VM, Heino J. Integrin alpha 2 beta 1 promotes activation of protein phosphatase $2 \mathrm{~A}$ and dephosphorylation of Akt and glycogen synthase kinase 3 beta. Mol Cell Biol. 2002; 22:1352-9. 
37. Higuchi K, Inokuchi M, Takagi Y, Ishikawa T, Otsuki S, Uetake H, Kojima K, Kawano T. Cadherin 5 expression correlates with poor survival in human gastric cancer. J Clin Pathol. 2017; 70:217-21.

38. Popović A, Demirović A, Spajić B, Stimac G, Kruslin B, Tomas D. Expression and prognostic role of syndecan-2 in prostate cancer. Prostate Cancer Prostatic Dis. 2010; 13:78-82.

39. Yoneda M, Hirokawa YS, Ohashi A, Uchida K, Kami D, Watanabe M, Yokoi T, Shiraishi T, Wakusawa S. RhoB enhances migration and MMP1 expression of prostate cancer DU145. Exp Mol Pathol. 2010; 88:90-5.

40. Riikonen T, Westermarck J, Koivisto L, Broberg A, Kähäri VM, Heino J. Integrin alpha 2 beta 1 is a positive regulator of collagenase (MMP-1) and collagen alpha 1(I) gene expression. J Biol Chem. 1995; 270:13548-52.

41. Ferraris GM, Schulte C, Buttiglione V, De Lorenzi V, Piontini A, Galluzzi M, Podestà A, Madsen CD, Sidenius $\mathrm{N}$. The interaction between $\mathrm{UPAR}$ and vitronectin triggers ligand-independent adhesion signalling by integrins. EMBO J. 2014; 33:2458-72.

42. Gupta J, Nebreda AR. Roles of p38a mitogen-activated protein kinase in mouse models of inflammatory diseases and cancer. FEBS J. 2015; 282:1841-57.

43. Koul HK, Pal M, Koul S. Role of p38 MAP kinase signal transduction in solid tumors. Genes Cancer. 2013; 4:34259. https://doi.org/10.1177/1947601913507951.

44. Che JP, Li W, Yan Y, Liu M, Wang GC, Li QY, Yang B, Yao XD, Zheng JH. Expression and clinical significance of the nin one binding protein and p38 MAPK in prostate carcinoma. Int J Clin Exp Pathol. 2013; 6:2300-11.
45. Rousseau S, Houle F, Landry J, Huot J. p38 MAP kinase activation by vascular endothelial growth factor mediates actin reorganization and cell migration in human endothelial cells. Oncogene. 1997; 15:2169-77.

46. Shen KH, Hung SH, Yin LT, Huang CS, Chao CH, Liu CL, Shih YW. Acacetin, a flavonoid, inhibits the invasion and migration of human prostate cancer DU145 cells via inactivation of the p38 MAPK signaling pathway. Mol Cell Biochem. 2010; 333:279-91.

47. Ivaska J, Käpylä J, Pentikäinen O, Hoffrén AM, Hermonen J, Huttunen P, Johnson MS, Heino J. A peptide inhibiting the collagen binding function of integrin alpha2I domain. J Biol Chem. 1999; 274:3513-21.

48. Kim D, Pertea G, Trapnell C, Pimentel H, Kelley R, Salzberg SL. TopHat2: accurate alignment of transcriptomes in the presence of insertions, deletions and gene fusions. Genome Biol. 2013; 14:R36.

49. Liao Y, Smyth GK, Shi W. featureCounts: an efficient general purpose program for assigning sequence reads to genomic features. Bioinformatics. 2014; 30:923-30.

50. Smyth GK. Limma: linear models for microarray data. In: Gentleman R, Carey V, Dudoit S, Irizarry R, Huber W, editors. Bioinformatics and Computational Biology Solutions using $\mathrm{R}$ and Bioconductor. New York: Springer; 2005. pp. 397-420.

51. Livak KJ, Schmittgen TD. Analysis of relative gene expression da ta using real-time quantitative PCR and the 2(- $\Delta \Delta \mathrm{C}(\mathrm{T}))$ Method. Methods. 2001; 25:402-08.

52. Guzmán C, Bagga M, Kaur A, Westermarck J, Abankwa D. ColonyArea: an ImageJ plugin to automatically quantify colony formation in clonogenic assays. PLoS One. 2014; 9:e92444. 